\title{
Platelet Dopamine Uptake in Huntington's Chorea and Gilles de la Tourette's Syndrome: Effect of Haloperidol
}

\author{
ROGER F. BUTTERWORTH, MICHEL GONCE, AND ANDRÉ BARBEAU
}

\begin{abstract}
SUMMARY: Uptake of ${ }^{14} \mathrm{C}$-dopamine by human platelets has been studied in two diseases, namely Gilles de la Tourette's syndrome and Huntington's chorea, in which abnormal metabolism of dopamine has been implicated. Platelets from untreated Huntington's chorea patients showed a small increase in Km and $V$ max.; platelets from patients in all other groups showed an uptake identical with
\end{abstract}

RÉSUMÉ: La captation de la dopamine C-14 par les plaquettes humaines a été étudiée dans deux autres maladies extrapyramidales chex lesquelles une anomalie du métabolisme de la dopamine a été impliquée. Les plaquettes des patients choréiques non traités montrent une légère augmentation du $\mathrm{Km}$ et du Vmax., alors que ces chiffres sont normaux dans les autres groupes. Nous avons également confirmé que l'haloperidol, efficace dans ces maladies, est 1 n inhibiteur

From the Department of Neurology, Clinical Research Institute of Montreal.

Reprint requests to: Dr. André Barbeau, Department of Neurology, Clinical Research Institute of Montreal, 110 Pine Avenue West, Montreal, Quebec H2W IR7. the controls. Haloperidol $\left(10^{-5} \mathrm{M}\right)$ was also shown to be a strong non-competitive inhibitor of ${ }^{14} C-D A$ uptake by platelets. This property is probably anrelated to the drugs' action in ameliorating the symptoms of Huntington's chorea which is likely related to the increase in cholinergic neuronal activity produced by nearoleptic blockade of dopamine receptors.

non-compétitif paissant de la captation de la dopamine marquée par les plaquettes. Cependant cette action est probablement indépendante des résultats cliniques favorables notés avec cette drogue dans la chorée de Huntington et la maladie de Gilles de la Tourette. Nous postulons que celte action thérapeutique se rapproche surtout des modifications cholinergiques secondairement produites lorsque l'on bloque les récepteurs dopaminergiques.

\section{INTRODUCTION}

Transport of biogenic amines by human platelets shows many similarities to synaptosomal preparations (Paasonen, 1973). In addition, platelet amine uptake is abnormal in Down's syndrome (Lott et al., 1972), Duchenne muscular dystrophy (Murphy et al., 1973) and Parkinson's disease (Barbeau et al., 1975). The decreased accumulation of dopamine by Parkinsonian patients' platelets offered the first evidence that the dopamine defect was of a more generalized nature (Barbeau et al., 1975). The present study was undertaken to look for similar deficits in two other diseases in which disordered dopamine metabolism has been implicated, namely Huntington's chorea and Gilles de la Tourette's syndrome. Aminoff et al. (1974) reported the plasma uptake of dopamine and serotonin is significantly elevated in patients with Huntington's chorea.

\section{SUBJECTS, MATERIALS AND METHODS}

Subjects

A. Controls

Eleven normal volunteer subjects of either sex were chosen with ages ranging from 17 to $45 \mathrm{yr}$. One control subject was always studied at the same time as a patient.

B. Huntington's Chorea patients Six patients with varying degrees of severity of the disease, ages ranging from 21 to $53 \mathrm{yr}$. were divided into two groups of 3 ; group 1 patients had been treated with haloperidol, group 2 patients had not been treated with haloperidol. 
C. Gilles de la Tourette's patients

Five patients with varying degrees of severity of the disease and age range 20 to $43 \mathrm{yr}$. were studied.

\section{Materials}

${ }^{14} \mathrm{C}$-dopamine $\left({ }^{14} \mathrm{C}-2 \mathrm{C}\right.$-ethylamine) (dopamine), specific activity $50 \mathrm{mci} /$ m.md. was obtained from the Radiochemical Centre, Amsterdam. Dopamine ( 3 hydroxytyramine) hydrochloride was purchased from Calbiochem. Haloperidol (Haldol) was purchased from McNeil Laboratories, Don Mills, Ontario, Canada.

\section{Methods}

Preparation of platelet-rich plasma, platelet count and uptake of ${ }^{14} \mathrm{C}$-dopamine by platelets was done as previously described (Barbeau et al., 1975).

\section{Kinetics of uptake of ${ }^{14} \mathrm{C}$-dopa-} mine by platelets

$1 \mathrm{ml}$ samples of platelet-rich plasma were incubated at $37^{\circ} \mathrm{c}$ for 30 min. with ${ }^{14} \mathrm{C}-\mathrm{DA}$ of the following concentrations: $10.0 \times 10^{-5} \mathrm{M}$., $2.0 \mathrm{x}$ $10^{-5} \mathrm{M}$., $1.0 \times 10^{-5} \mathrm{M}$., and $0.5 \mathrm{x}$ $10^{-5} \mathrm{M}$. Platelets were then isolated by centrifugation $(8000 \mathrm{G}$., $5 \mathrm{~min}$., $4^{\circ} \mathrm{C}$ ), disrupted by sonification and assayed for radioactivity as previously described (Barbeau et al., 1975). The kinetics of uptake of dopamine by the platelet were evaluated by relating the velocity of uptake of this amine to its concentration in the medium by the method of Lineweaver and Burk (1934). The influence of haloperidol $\left(10^{-5} \mathrm{M}\right.$.) on the platelet uptake of ${ }^{14} \mathrm{C}$-dopamine was studied by including this compound at the appropriate concentration in the incubation medium.

\section{RESULTS}

Human platelets were found to accumulate dopamine when incubated in plasma containing ${ }^{14} \mathrm{C}$-labelled dopamine, as shown in Table 1. The Gilles de la Tourette's patients' platelets showed a tendency toward more rapid accumulation of dopamine at initial times, but these differences were not significant as analysed by Student $t$ test . Huntington's chorea patients' platelets were found to take up dopamine at the same rates as agematched controls.

When platelets from normal individuals were incubated in plasma containing ${ }^{14} \mathrm{C}$-dopamine, the rate of uptake was as shown in Figure 1, as studied by Lineweaver and Burk kinetic analysis. From Figure 1, the mean value for $\mathrm{Km}$ was $3.7 \times 10^{-5} \mathrm{M}$. DA. Ranges of values for the control population studied by us were found to be $2.22-5.10 \times 10^{-5} \mathrm{M}$.

When haloperidol $\left(10^{-5} \mathrm{M}\right.$.) was included in the incubation mixture, a strong non-competitive inhibition was seen, as shown in Figure 1. $\mathrm{K}_{\mathrm{i}}$ for inhibition, as obtained by Dixon plot was $1.0 \times 10^{-5} \mathrm{M}$.

When the kinetics of uptake of ${ }^{14} \mathrm{C}$-dopamine by platelets were analysed by the method of Lineweaver and Burk (1934) for controls and patients, values for $\mathrm{Km}$ and Vmax. were obtained and are shown in Table 2.

Although controls and patients do not show any major differences in $\mathrm{Km}$ and Vmax., it is interesting to note that there is a tendency by platelets of untreated Huntington's chorea patients to show an increased $\mathrm{V} \max$. and $\mathrm{Km}$ compared to those patients receiving haloperidol for treatment of the disease.

\section{DISCUSSION}

The primary defect in Parkinson's disease is a massive degenerative loss of the dopaminergic neurons of the nigro-striatal pathway. These neurons appear to be present in normal amounts in the basal ganglia in Huntington's chorea (Barbeau, 1975). Loss of GABA-containing neurons from the basal ganglia in Huntington's chorea cannot explain the extrapyramidal movement disorder seen in this disease since a similar loss of GAD activity occurs in the basal ganglia tissue of Parkinson's disease and Alzheimer's presenile dementia. A more likely explanation might involve the interelationship between dopamine and acetylcholine in these two diseases. There is good evidence that choreiform movements are associated with an enhanced receptor response to dopamine in extrapyramidal structures and, furthermore, the most effective drugs reducing choreiform movements are catecholamine depleting agents such as reserpine and dopamine-receptor antagonists like chlorpromazine and haloperidol (Barbeau, 1973).

It has been reported that the uptake of dopamine by platelet-rich plasma from patients with Huntington's chorea was significantly greater than controls (Aminoff et al., 1974; McLean and Nihei, 1977), while the uptake in Gilles de la Tourette's syndrome has not previously been reported. The present study shows that the platelet uptake of dopamine in the two diseases is not different from the controls. This is in contrast to Parkinsonian patients

TABLE I

UPTAKE OF DOPAMINE BY HUMAN PLATELETS

\begin{tabular}{|l|c|c|c|c|c|c|}
\cline { 3 - 7 } \multicolumn{1}{c|}{} & \multirow{2}{*}{$\mathbf{N}$} & \multicolumn{5}{|c|}{ UPTAKE } \\
\cline { 3 - 8 } \multicolumn{1}{c|}{} & & $\mathbf{1 0} \mathbf{~ m i n .}$ & $\mathbf{6 0} \mathbf{~ m i n .}$ & $\mathbf{9 0} \mathbf{~ m i n .}$ & $\mathbf{1 2 0} \mathbf{~ m i n .}$ & $\mathbf{1 8 0} \mathbf{~ m i n .}$ \\
\hline CONTROLS & 11 & $7.43 \pm 0.79$ & $39.19 \pm 2.72$ & $49.50 \pm 3.0$ & $54.72 \pm 2.42$ & $56.37 \pm 2.62$ \\
\hline HUNTINGTON'S CHOREA & 6 & $8.76 \pm 0.82$ & $38.13 \pm 3.51$ & $53.07 \pm 4.27$ & $57.98 \pm 6.12$ & $59.61 \pm 8.52$ \\
\hline GILLES DE LA TOURETTE'S & 5 & $9.11 \pm 1.31$ & $44.64 \pm 5.71$ & $48.41 \pm 8.12$ & $55.49 \pm 4.73$ & $56.69 \pm 8.70$ \\
\hline
\end{tabular}


who have a markedly decreased platelet dopamine uptake (Barbeau et al., 1975). It appears that altered uptake of dopamine cannot be used with reliability as a predictive test as previously suggested (McLean and Nihei, 1977).

Kinetics of the accumulation of dopamine by the human platelet were studied by the method of Lineweaver and Burk (1934). A mean $\mathrm{Km}$ value for platelets from normal volunteers of $3.70 \times 10^{-5} \mathrm{M}$. DA was obtained with a range of values from $2.22-5.10$ $x 10^{-5} \mathrm{M}$. DA. This is in good general agreement with the value for $\mathrm{Km}$ of $6.7 \times 10^{-5} \mathrm{M}$. DA published by Solomon et al. (1970) using a slightly modified technique. In vivo studies show (Figure 1) that haloperidol $\left(10^{-5} \mathrm{M}\right.$.) produces a strong noncompetitive inhibition of platelet dopamine uptake. This in vivo action of haloperidol is likely unrelated to the drug's action in producing improvement of the symptoms of Huntington's chorea or Gilles de la Tourette's syndrome. Previously, other neuroleptics, including chlorpromazine, have been shown to inhibit non-competitively the uptake of dopamine by synaptosomes from corpus striatum (Horn et al., 1971), while another study (Solomon et al., 1970) reported that haloperidol $\left(10^{-4} \mathrm{M}\right.$.) produced a $90 \%$ inhibition of dopamine uptake by human blood platelets.

It is difficult to reconcile the antichorea action of haloperidol with these observations. It has been suggested (Kehr et al., 1972) that haloperidol acts both pre and post synaptically, while the drug's action in ameliorating the symptoms of Huntington's chorea and Gilles de la Tourette's syndrome is generally considered to be a result of postsynaptic receptor blockade. Perhaps other neuroleptics having a more purely post-synaptic action (such as pimozide) may be more useful in the treatment of these disorders. Indeed, Fog and Pakkenberg (1970) reported that pimozide combined with tetrabenazine improved chorea in 9 out of 12 patients. Improvement using pimozide aline in 2 patients could not, however, be found by others (Lal et al., 1973).

Bird and Iversen (1974) reported that choline acetyltransferase activity was decreased in brain tissue of patients dying with Huntington's chorea. This decreased activity appeared to have been restored in patients who were treated with neuroleptics. Neuroleptics blockade of dopamine receptors has been shown to enhance acetycholine turnover (Stadler et al., 1973); the mechanism of this action, however, remains to be fully understood. It is of interest to note that beneficial results have been observed in chorea and tardive dyskinesia by treatment with choline (Davis et al., 1976; Growdon et al., 1977).

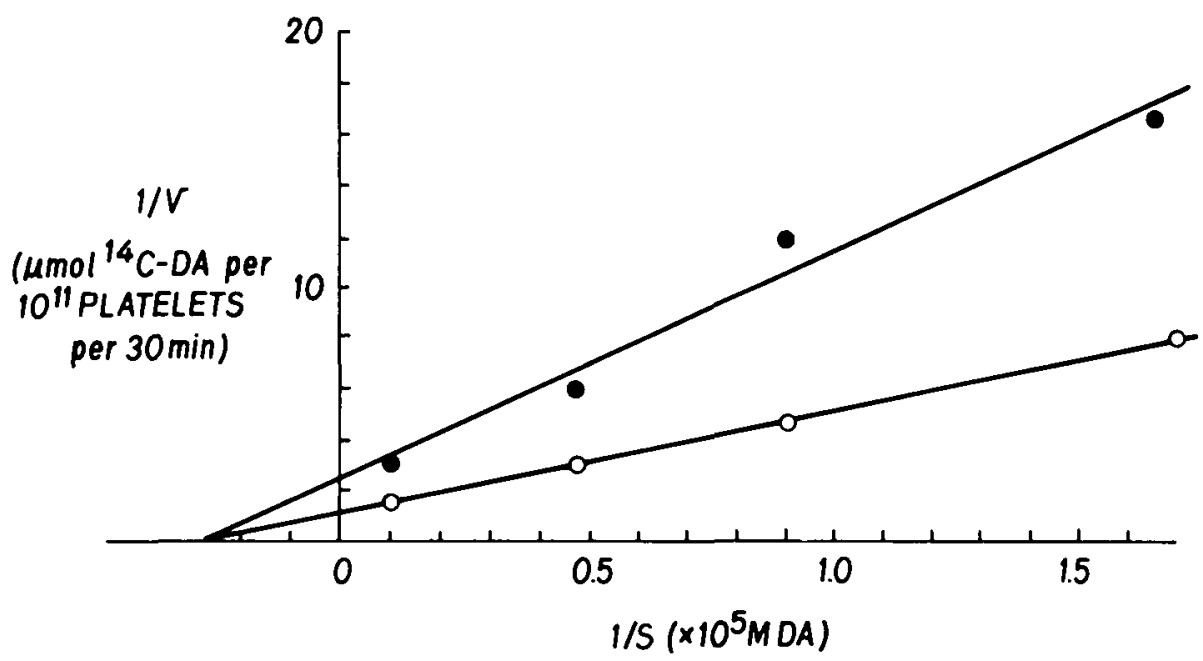

Figure 1-Kinetics of inhibition of uptake of dopamine by haloperidol in human platelets. Platelets were incubated in the presence of $(O)$ and in the absence of $(0)$ haloperidol $10^{-5} \mathrm{M}$.

TABLE 2

KINETICS OF UPTAKE OF ${ }^{14} \mathrm{C}$-DOPAMINE BY PLATELETS

\begin{tabular}{|c|c|c|c|c|}
\hline & $\mathbf{N}$ & $\begin{array}{c}\text { MEAN AGE } \\
\text { (YR.) }\end{array}$ & $\begin{array}{c}\text { Vmax. } \\
\text { n mol. 14C-DA PER } \\
\mathbf{1 0}^{\prime} \text { PLATELETS PER 30 MIN. }\end{array}$ & $\begin{array}{c}\text { Km } \\
\text { (x 10-5 M. DA) }\end{array}$ \\
\hline CONTROLS & 11 & 27.3 & $0.97 \pm 0.08$ & $3.70 \pm 0.29$ \\
PATIENTS & & & & \\
GILLES DE LA TOURETTE & 5 & 28.6 & $0.77 \pm 0.11$ & $3.80 \pm 0.91$ \\
HUNTINGTON'S CHOREA & 6 & 32.3 & $1.02 \pm 0.12$ & $4.15 \pm 0.84$ \\
Haloperidol Treated & 3 & 31.7 & $0.98,0.95,0.52$ & $3.05,3.68,1.42$ \\
Untreated & 3 & 33.0 & $1.16,1.35,1.18$ & $7.54,5.14,4.07$ \\
\hline
\end{tabular}




\section{ACKNOWLEDGEMENTS}

These studies were supported in part by grants from the Medical Research Council of Canada (MT-4938), the United Parkinson Foundation and the W. Garfield Weston Foundation.

The authors would like to express their gratitude to Mrs. France Landreville and Miss Francine Bélanger for their technical assistance and to Mrs. Monique Savard for typing the manuscript.

\section{REFERENCES}

AMINOFF, M. J., TRENCHARD, A., TURNER, P., WOOD, W. G. HILLS, M. (1974). Plasma uptake of dopamine and 5-hydroxytryptamine and plasma catecholamine levels in patients with Huntington's chorea. Lancet, 1115-1116.

BARBEAU, A. (1973). Biochemistry of Huntington's chorea. In: Huntington's chorea 1872-1972. Advances in Neurology, Volume I, (Barbeau, A., Chase, T. N. and Paulson, G. W., eds.). Raven Press. New York. pp. 473-516.

BARBEAU. A. (1975). Maladies du Système extrapyramidal. In: Pathologie Médicale (Pequignot, H., ed.). Masson \& Cie, Paris, pp. 1446-1453.

BARBEAU, A., CAMPANELLA. G., BUTTERWORTH, R. F. and YAMADA. K. (1975). Uptake and Efflux of ${ }^{14} \mathrm{C}$-dopamine by platelets: Evidence for a generalised defect in Parkinson's disease. Neurol., 25, $1-9$.

BIRD, E. D. and IVERSEN, L. L. (1974). Huntington's chorea, post mortem measurement of glutamic acid decarboxylase, choline acetyl transferase and dopamine in basal ganglia. Brain, 97, 457-472.

DAVIS, K. L., HOLLISTER, L. E., BARCHAS, J. D. and BERGER, P. A. (1976). Choline in tardive dyskinesia and Huntington's disease. Life Sciences, 19, $1507-1516$.

FOG, H. and PAKKENBERG, H. (1970). Combined nitroman-pimozide treatment of Huntington's chorea and other hyperkinetic syndromes. Acta Neurol. Scand., 46. 249-251.

GROWDON, J. H., COHEN, E. L. and WURTMAN. R. J. (1977). Effects of oral choline administration on serum and CSF choline levels in patients with Huntington's disease. J. Neurochem., 28, 229-231.

HORN, A. S., COYLE, J. T. and SNYDER, S. H. (1971). Catecholamine uptake by synaptosomes from rat brain. Mol. Pharmacol., 7, 66-80.

KEHR, W., CARLSSON, A., LINDQUIST, M.. MAGNUSSON. T. and ATACK, C. (1972). Evidence for a receptor-mediated feedback control of striatal tyrosine hydroxylase activity. J. Pharm. Pharmac., 24. 744-747.
LAL, S., DE LA VEGA, C., GARELIS, E. and SOURKES, T. L. (1973). Apomorphine, pimozide, L-DOPA and the probenecid test in Huntington's chorea. Psychiat., Neurol., Neurochir., 76, 113-117.

LINEWEAVER, H. and BURK, D. (1934). The determination of enzyme dissociation constants. J. Am. Chem. Soc., 56, 658-666.

LOTT, I. T., CHASE, T. N. and MURPHY, D. L. (1972). Down's syndrome: transport, storage and metabolism of serotonin in blood platelets. Pediat. Res., 6, 730-735.

MCLEAN, D. R. and NIHEI, I. (1977). Uptake of dopamine and 5-hydroxytryptamine by platelets from patients with Huntington's chorea. Lancet, 1, 249-250.

MURPHY, G. F., MENDELL, J. R. and ENGEL, W. K. (1973). Serotonin and platelet function in Duchenne muscular dystrophy. Arch. Neurol., 28, 239-242.

PAASONEN, M. K. (1973). Blood platelets as a model for aminergic neurons. In: Pharmacology and the Future of Man, Vol. 4, (Karger, S., ed.). Basel, pp. 328-342.

SOLOMON, H. M., SPIRT, N. M. and ABRAMS, W. B. (1970). The accumulation and metabolism of dopamine by the human platelet. Clin. Pharmacol. Ther., II, 838-845.

STADLER, H., LLOYD, K. G., GADEACIRIA. M. and BARTHOLINI. G. (1973). Enhanced striatal acetylcholine release by chlorpromazine and its reversal by apomorphine. Brain Res., 55. 476-480. 